\title{
Prevalence of Nosema species in a feral honey bee population: a 20-year survey
}

\author{
Juliana RANGEL ${ }^{1}$, Kristen BAUM ${ }^{2}$, William L. RUBINK ${ }^{3}$, Robert N. CoULSON ${ }^{4}$, \\ J. Spencer Johnston ${ }^{1}$, Brenna E. TRAVER ${ }^{5}$

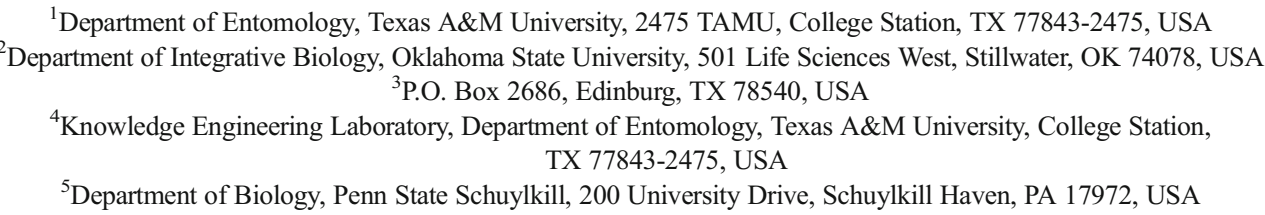

Received 26 January 2015 - Revised 14 July 2015 - Accepted 20 October 2015

\begin{abstract}
Nosema spp. are microsporidian pathogens of honey bees that cause nosemosis, a disease implicated in colony losses worldwide. Few studies have measured Nosema spp. levels in feral honey bees. We evaluated the presence and infection intensity of Nosema apis and Nosema ceranae in a feral Africanized honey bee population in south Texas from 1991 to 2001 and in 2013. Overall, less than $6 \%$ of samples had Nosema spp. spores. N. apis was only found in samples from 1991 to 1995 . Conversely, N. ceranae was found every year examined, ranging from $16.7 \%$ infection in 1991 to $85.7 \%$ in 2013 . There were no effects of temperature or rainfall on infection with either species over time. This suggests that feral honey bees are relatively free of Nosema spp. compared to managed colonies. More studies on the incidence of Nosema spp. in feral honey bee populations are needed.
\end{abstract}

\section{Apis mellifera / Africanized feral honey bees / Nosema apis / Nosema ceranae / qPCR}

\section{INTRODUCTION}

Nosemosis, a disease of honey bees that infects epithelial cells of the midgut (Bailey 1981; Matheson 1993), can be caused by the presence of microsporidia species in the genus Nosema (Nosematidae). Nosemosis is transmitted horizontally between adults through the oral-fecal route, where uninfected adults become infected by contact with food or feces contaminated with Nosema spp. spores (Fries 1993, 1996). Following ingestion, spores germinate within the midgut by ejecting a polar filament that injects the Nosema spp. sporoplasm into epithelial cells of the midgut.

Corresponding author: J. Rangel, jrangel@tamu.edu

Manuscript editor: Yves Le Conte
Vegetative stages reproduce within the cells to form spores that are released upon lysis of the cell, which then are freed to infect other midgut epithelial cells (Bailey and Ball 1991). Two species of Nosema can infect the honey bee Apis mellifera: Nosema apis and Nosema ceranae.

$N$. apis affects the western European honey bee (Apis mellifera L.) and is found worldwide (Matheson 1996). N. ceranae was first discovered in the Asian honey bee Apis cerana in 1996 (Fries 1996), was later identified in managed Apis mellifera colonies in Spain and Taiwan (Higes et al. 2006; Huang et al. 2007), and is now widespread in Europe (Higes et al. 2006, 2009a; Chauzat 2007; Huang et al. 2007, 2008; Klee et al. 2007; Paxton et al. 2007; Topolska and S. Kasprzak 2007), North America (Chen et al. 2008; Williams et al. 2008; Traver and Fell 2011a, b), Central America (Calderón 2008; 
Rangel et al. 2013), South America (Invernizzi et al. 2009; Medici et al. 2012; Mendoza et al. 2014), Africa (Fries 2003; Higes et al. 2009b), and Australia (Giersch et al. 2009). While honey bee colonies infected with $N$. apis exhibit fecal streaking on the hives and comb due to severe dysentery (Hassanein 1951; Fries 1993), those infected with $N$. ceranae do not show obvious external symptoms. Despite the key symptomatic differences caused by different Nosema species, infection with one or both species causes significant declines in a colony's overall worker population (Wang and Mofller 1970; Higes et al. 2008) and honey production (Hassanein 1951; Fries et al. 1984; Rinderer and Sylvester 1978; Anderson and Giacon 1992; Malone et al. 1995).

The decrease in the worker population (colony size) is mainly caused by worker mortality associated with digestive disorders and shortened lifespan (Hassanein 1951). Antúnez et al. (2009) showed evidence that $N$. ceranae infections result in immunosuppression in workers, hypothesizing that $N$. ceranae infection can make a colony more susceptible to other pathogens, particularly viruses (Bailey et al. 1983; Dainat et al. 2012). Several studies have also reported detrimental synergistic interactions between $N$. ceranae and other stressors such as pesticides, on honey bee health (Alaux et al. 2010; Vidau et al. 2011; Wu et al. 2012; Higes et al. 2013).

Colonies may be infected by one or both strains of Nosema. A recent study found direct evidence suggesting that $N$. ceranae and $N$. apis undergo severe interspecific competition inside the gut of honey bees and that when co-infecting bees with both microsporidia, $N$. ceranae infection exhibited stronger inhibition of $N$. apis than vice versa (Natsopoulou et al. 2014). Because the spores of both species look very similar using traditional miscroscopy, the cause of nosemosis, whether by $N$. apis or $N$. ceranae, or both, is most reliably distinguished using polymerase chain reaction (PCR) (Martin-Hernandez et al. 2007; Roudel et al. 2013) and quantitative polymerase chain reaction (qPCR) techniques (Higes et al. 2006; Klee et al. 2007; Paxton et al. 2007; Traver and Fell 2011a, b; Rangel et al. 2013).

N. apis will infect the African honey bee, Apis mellifera scutellata, causing diagnostic symptoms that are similar to those found in infected European honey bees (Fries 2003). Feral and managed honey bee colonies in Central and South America, as well as some regions in the southern United States are considered "Africanized," or hybrids formed from a mixture of genes derived from European and African ancestors (Taylor 1988; Taylor and Spivak 1984; Rubink et al. 1996; Pinto 2004). Interestingly, infection of workers by Nosema in Latin America is observed mostly in Africanized honey bees. However, that observation may reflect incomplete sampling, as most studies of nosemosis in Africanized honey bees in that region have been done in managed colonies (Calderón 2008; Invernizzi et al. 2009; Rangel et al. 2013; Mendoza et al. 2014).

There have only been three studies reporting Nosema levels in unmanaged honey bees living as feral colonies in diverse habitats, and those three studies only reported N. apis infection. Manning et al. (2007) reported high levels of $N$. apis infection in feral honey bee colonies around southwestern Australia from 2002 to 2003. While all the colonies surveyed were infected with $N$. apis, the presence and severity of infection were significantly affected by the location of the colony and the weather during sample collection. In the USA, only two studies have reported the prevalence of Nosema spp. in feral Africanized honey bees. Gilliam and Taber (1991) first reported the presence of $N$. apis in feral honey bees from Arizona, where they found a very low level of infection, with 9 of 21 individuals sampled being infected with only one to five $N$. apis spores per infected bee. More recently, Szalanski (2014) explored the prevalence of Nosema spp. in feral Africanized honey bees in Arkansas, New Mexico, Mississippi, New Mexico, Oklahoma, Texas, and Utah. Using PCRrestriction fragment length polymorphism (PCRRFLP), the authors found that only $8.3 \%$ of the samples analyzed tested positive for $N$. apis, with infections being more common in Texas than in any other state surveyed.

All of the aforementioned surveys were done only for $N$. apis and were conducted on samples collected in a single year. Therefore, data are lacking on the presence of $N$. apis and $N$. ceranae in feral honey bee populations in the USA over time. In this study, we surveyed the same population of feral honey bees in 
south Texas from 1991 to 2001 and again in 2013 and used molecular techniques to determine the presence and levels of infection in these colonies by N. apis, N. ceranae, or both, over the last two decades.

\section{METHODS}

\subsection{Study site and sample collection}

The feral honey bees sampled for this study were collected at the Welder Wildlife Refuge (WWR), located in San Patricio County, TX (28 07' 18', $-97^{\circ} 26^{\prime}$ 34"). The WWR lies between the Gulf Prairies and Marshes and the South Texas Plains ecoregions, which constitute a transitional zone composed mostly of mesquite, chaparral brushland, open grassland, and abundant live oak tress (Drawe et al. 1978; Blankenship 2000). Typically, this area experiences a year-round humid climate, with hot summers and cool winters (Blankenship 2000; Baum 2003).

Baum $(2003 ; 2005)$ surveyed a $6.25-\mathrm{km}^{2}$ area of the WWR every year between 1991 and 2001 and found a total of 109 trees housing feral honey bee colonies, with most of the colonies living in standing oak trees (85\%) while the remaining colonies lived in elm or fallen oaks. During the survey, honey bee workers were collected from all active colonies every year for mitochondrial and genomic DNA analysis. This was done to investigate the patterns of hybridization between bees of European and African descent occurring in this population of feral honey bees since the late 1990s (Baum 2003; 2005; Pinto 2004; Pinto 2005). In 2013, $5.60 \mathrm{~km}^{2}$ of the original WWR study area was resurveyed, and 89 of the original 109 trees that had been identified earlier were re-visited and sampled for honey bees if a colony was present.

In the current study, honey bee workers were selected from the 2013 population and from a subsample of the colonies sampled in previous years. The colonies used for Nosema spp. analysis were those with honey bees that inhabited the same tree cavities over multiple years, and those with at least 60 workers that could be examined for spore counts. In total, we analyzed worker samples from 18 tree cavities inhabited by honey bees in seven different years: 1991, 1992, 1994, 1995, 1998, 2001, and 2013. No samples were collected between 2001 and 2013.

\subsection{Genomic DNA extraction and quantitative real-time PCR}

Genomic DNA was extracted from individual abdomens of ten workers from each cavity sampled per year as described previously (Traver et al. 2009; Traver and Fell 2011a). Briefly, a Bender buffer lysis followed by a proteinase $\mathrm{K}$ digestion and phenol/chloroform extraction was performed. After the first separation step, the organic layer was saved for spore analysis. DNA was precipitated with isopropanol and resuspended overnight in DEPC-treated water kept at room temperature. This procedure resulted in the extraction of genomic DNA from vegetative cells but not from mature spores. DNA purity and concentration were assessed using a Nanodrop 2000 Spectrophotometer (Thermo Scientific, Wilmington, DE, USA). Subsamples from five random DNA samples were pooled together to reduce the sample size for analysis. Pools of five DNA samples were collected twice for each sample, as there was individual DNA from ten bees from each colony sampled.

A qPCR was subsequently performed following the protocols described by Traver and Fell (2011a). Briefly, Nosema species-specific TaqMan Gene Expression assays (Applied Biosystems, Foster City, CA, USA) were used to quantify infection levels and to identify the Nosema species present in each colony sampled. Absolute quantitation, using standard curves with known $N$. ceranae and $N$. apis DNA copy numbers, was used to estimate the levels of infection of each Nosema species across all colonies sampled per year. All qPCRs were performed using an Applied Biosystems StepOne ${ }^{\mathrm{TM}}$ Real-Time PCR System. A 20$\mu \mathrm{L}$ reaction for duplex qPCR was performed according to the TaqMan Gene Expression Master Mix protocol (Applied Biosystems, Foster City, CA, USA) using $50 \mathrm{ng}$ of total pooled genomic DNA per reaction. Standard controls as well as the experimental samples were run together and the average cycle threshold value $\left(C_{\mathrm{T}}\right)$ was used to calculate the average copy number of each species of Nosema present in each DNA sample (Traver and Fell 2011a).

\subsection{Nosema spore counts}

Spores were counted as previously described, a method that carefully ensures that only Nosema spores, not those of other microorganisms, are tallied (Cantwell 1970; Mulholland et al. 2012). Briefly, ten workers were 
examined per colony by dissecting out their abdomens. Each abdomen pellet was crushed and microscopically examined to estimate the average number of Nosema spp. spores found per worker from each colony. Spores were counted on a Bright-Line Hemacytometer (Hausser Scientific, Horsham, PA) to estimate the number of spores per individual worker abdomen as described previously (Cantwell 1970; Mulholland et al. 2012). The average number of spores per colony, for each year, was calculated by averaging the number of spores per bee from each cavity sampled.

\subsection{Temperature and precipitation across years}

Because most of the bees were collected in the month of July across years, we evaluated if mean temperature or rainfall patterns in July at the WWR had an effect on the prevalence of either Nosema species. To answer this question, we queried the monthly climatological summary from the Welder Wildlife Foundation weather station (elevation, $49 \mathrm{ft}$.; latitude, $28.114^{\circ} \mathrm{N}$; longitude, $97.418^{\circ} \mathrm{W}$ ) operated by the National Oceanic and Atmospheric Administration of the US Department of Commerce from 1991 to 2001, and again for 2013. The data include mean temperature $\left({ }^{\circ} \mathrm{C}\right)$ and total precipitation $(\mathrm{mm})$ recorded at the station in July.

\subsection{Statistical analysis}

A Kruskal-Wallis test was performed to determine whether the mean number of Nosema spp. spores per bee varied significantly across years. We used a least squares analysis of variance test with the software JMP 11 Pro (SAS Institute Inc., Cary, NC) to test whether temperature and rainfall had a significant effect on the average copy numbers of $N$. ceranae or $N$. apis found across years. All descriptive statistics are reported as the mean \pm 1 standard error of the mean (SEM). We set the level of statistical significance at $\alpha=0.05$ for all tests.

\section{RESULTS}

\subsection{Nosema spp. spore counts}

We scored worker samples from 18 tree cavities inhabited by honey bees in 1991, 1992, 1994, 1995, 1998, 2001, and 2013 using spore counts and qPCR (Table I). Overall, colonies from feral honey bees at the WWR exhibited low spore counts. Of the 464 individual worker abdomens examined for spore counts, only 28 samples had spores present, representing only $5.9 \%$ of the total number of bees analyzed (Table I). In the bees with spores present, the mean number of spores per bee ranged significantly across years $\left(\chi^{2}=24.57\right.$; d.f. $\left.=9 ; P=<0.01\right)$, with the lowest number of spores observed in 1995 (357 \pm 357 spores per bee) and the highest number observed in $2001(13,405 \pm 10,161$; Table I).

\subsection{Nosema spp. infection intensities across years}

N. apis was found only in colonies sampled from 1991 to 1995 (Figure 1 and Table I). The percentage of colonies infected with $N$. apis was highest in 1991 (33.3 \%) and 1995 (14.3\%). The mean $N$. apis DNA copy number increased from nearly 12,000 DNA copies in 1991 to nearly 340,000 DNA copies in 1994, with only 24 copies observed in 1995 (Figure 2 and Table II). Colonies were co-infected with $N$. apis and $N$. ceranae from 1991 to 1995 at varying levels. We did not find $N$. apis in samples collected from 1998 to 2013, however (Figure 1 and Table II).

Although the feral honey bees at the WWR had low spore counts, $N$. ceranae was found in at least two of the colonies sampled every year. The percentage of colonies infected with $N$. ceranae varied between years, ranging from $16.7 \%$ in 1991 , $100 \%$ in 1994, and $85.7 \%$ in 2013 (Figure 1 and Table I). The mean $N$. ceranae DNA copy number per bee increased by 7 orders of magnitude from about 155 DNA copies in 1991 to over 88+ million DNA copies in 2013 (Figure 2 and Table II).

\subsection{Average temperature and rainfall patterns}

The mean temperature recorded in July at the WWR meteorological station ranged from 32.0 to $34.8{ }^{\circ} \mathrm{C}$. The temperature increased relatively steadily from 1991 to 1998, dropped by almost $3{ }^{\circ} \mathrm{C}$ in 1999 , and returned to temperatures above $34.7{ }^{\circ} \mathrm{C}$ in 2001 and 2013 (Figure 2). There were no obvious patterns in 
Table I. Mean spore count $( \pm \mathrm{SEM})$ from feral honey bee colony samples that tested positive for Nosema by spore analysis.

\begin{tabular}{llllll}
\hline $\begin{array}{l}\text { Year of } \\
\text { collection }\end{array}$ & $\begin{array}{l}\text { Total no. of } \\
\text { workers } \\
\text { analyzed }\end{array}$ & $\begin{array}{l}\text { Total no. of workers } \\
\text { that tested positive } \\
\text { for nosema spores }\end{array}$ & $\begin{array}{l}\text { \% workers with } \\
\text { nosema spores }\end{array}$ & $\begin{array}{l}\text { Mean spore } \\
\text { count per bee }\end{array}$ & $\begin{array}{l}\text { SEM spore } \\
\text { count per bee }\end{array}$ \\
\hline 1991 & 60 & 9 & 15.0 & $5.0 \times 103$ & $1.7 \times 103$ \\
1992 & 70 & 2 & 2.9 & $1.4 \times 103$ & $1.1 \times 103$ \\
1994 & 70 & 3 & 4.3 & $1.8 \times 103$ & $1.1 \times 103$ \\
1995 & 70 & 1 & 1.4 & 357.1 & 357.1 \\
1998 & 68 & 2 & 2.9 & $1.1 \times 103$ & 817.1 \\
2001 & 67 & 7 & 10.4 & $1.7 \times 104$ & $13.8 \times 10469$ \\
2013 & 69 & 4 & 5.8 & $1.3 \times 104$ & $10.2 \times 104$ \\
Total & 474 & 28 & & & \\
\hline
\end{tabular}

The samples were collected at the Welder Wildlife Refuge, San Patricio County, TX, from 1991 to 2001 and again for 2013

rainfall across the study years, with the total precipitation in July ranging from a low of $0 \mathrm{~mm}$ in 1993 to a high of about $140 \mathrm{~mm}$ in 1999, which also was the year with the lowest mean temperature in July (Figure 2). Overall, there were no clear effects of temperature or rainfall on the average DNA copy number of $N$. ceranae (F-ratio $=3.14 ; P=0.15$ ) or $N$. apis (F-ratio $=0.89 ; P=0.48$ ) found in the colonies sampled over time.

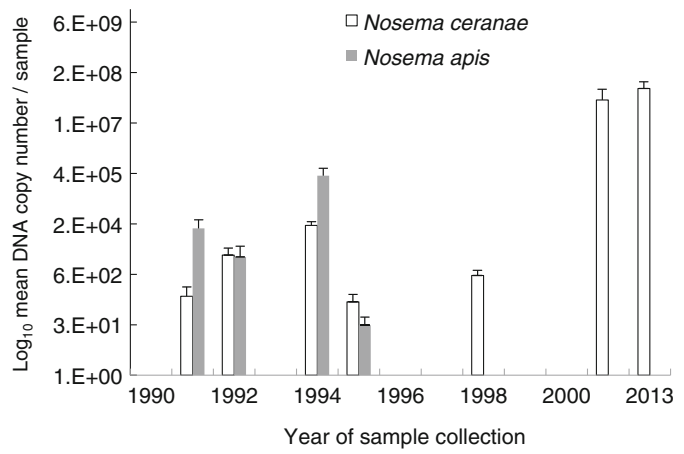

Figure 1. Nosema ceranae (white bars) and N. apis (gray bars ) mean copy numbers ( $\pm \mathrm{SEM}$ ) for feral honey bee colonies inhabiting tree cavities at the Welder Wildlife Refuge, San Patricio County, TX, from 1991 to 2001 and again for 2013. Two sets of five worker abdomens were used for a total of ten worker abdomens examined from each colony sampled. Species identification was done using qPCR analysis.

\section{DISCUSSION}

For over 20 years, the feral honey bee population at the WWR in south Texas has served as a valuable model for studies of biological invasion, species hybridization, and survival under adverse environmental conditions. We provide the first report of the combined prevalence and infection intensities of the microsporidia $N$. apis and $N$. ceranae in a population of feral honey bees in the USA. Overall, we found that the Nosema levels in this population are relatively low, with $N$. apis being present only in samples collected from 1991 to 1995 and subsequently disappearing by 1998. Conversely, the levels of $N$. ceranae escalated by 7 orders of magnitude from 1991 to 2013, suggesting that the decrease in prevalence of $N$. apis might have been in part due to competitive displacement by $N$. ceranae as has been hypothesized in other regions for managed colonies (Paxton et al. 2007). Furthermore, average rainfall or temperature did not have a clear impact on the levels of either Nosema species prevalence of infection levels over time.

N. apis was once the only Nosema species to infect Apis mellifera (Bailey and Ball 1991), with infection shown to reduce worker longevity by up to $50 \%$ and cause queen supersedure within 26 weeks (Moeller 1956; Bailey 1981). Related studies suggested that queen supersedure events 


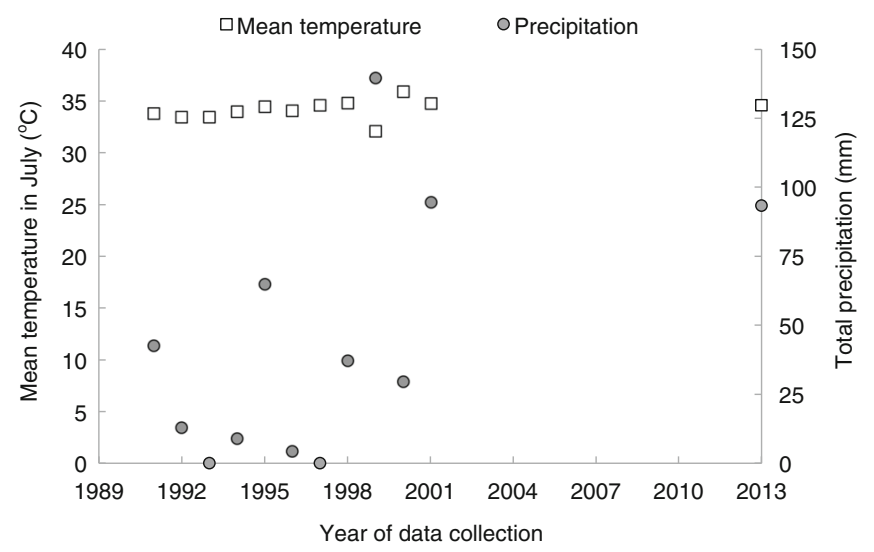

Figure 2. Average temperature and total precipitation in July recorded at the Welder Wildlife Foundation meteorological station of the National Oceanographic and Atmospheric Administration (elevation $49 \mathrm{ft}$., latitude 28.114 $\mathrm{N}$, longitude $97.418^{\circ} \mathrm{W}$ ). The values are provided for 1991 to 2001 and again for 2013 . The gap between 2001 and 2013 represents years in which data were not queried, as no honey bees were sampled those years.

occurred because of a $17-45 \%$ size reduction in the secretory globules of the hypopharyngeal glands of workers inoculated with $N$. apis spores (Wang and Moeller 1969). Furthermore, artificial inoculation of workers with $N$. apis spores negatively affected honey yield (Fries et al. 1994), suggesting that $N$. apis infection was directly associated with decreased colony productivity.
More recently, $N$. ceranae has been identified in managed honey bee colonies, first in Europe and Asia (Higes et al. 2006; Huang et al. 2007) and now on almost every continent where apiculture is practiced, including North America (Chen et al. 2008; Williams et al. 2008; Traver and Fell $2011 \mathrm{a}, \mathrm{b})$. The infectivity of $N$. ceranae seems more severe than that of

Table II. Infection levels of Nosema ceranae and N. apis found in feral honey bee colonies sampled at the Welder Wildlife Refuge, San Patricio County, TX, from 1991 to 2001, and again in 2013.

\begin{tabular}{llllllll}
\hline $\begin{array}{l}N . \text { ceranae } \\
\text { Year of } \\
\text { collection }\end{array}$ & $N$ & $\begin{array}{c}\text { Mean DNA } \\
\text { copy number } \\
\text { per bee }\end{array}$ & SEM & $\begin{array}{c}\text { \% colonies } \\
\text { infected } \\
\text { with } \\
N . \text { ceranae }\end{array}$ & $\begin{array}{c}\text { Mean DNA } \\
\text { copy number } \\
\text { per bee }\end{array}$ & SEM & $\begin{array}{c}\text { \% colonies } \\
\text { infected with } \\
\text { N. apis }\end{array}$ \\
1991 & 12 & 155.1 & 121.7 & 16.7 & $11,615.6$ & 8839.7 & 33.3 \\
1992 & 14 & 2131.0 & 1230.4 & 35.7 & 1905.0 & 1905.0 & 7.1 \\
1994 & 14 & $14,344.8$ & 3555.9 & 100 & $338,286.7$ & $201,187.3$ & 35.7 \\
1995 & 14 & 108.9 & 65.3 & 21.4 & 24.1 & 16.4 & 14.3 \\
1998 & 14 & 577.1 & 222.7 & 50.0 & 0 & 0 & 0 \\
2001 & 14 & $4.28 \times 107$ & $4.28 \times 107$ & 42.9 & 0 & 0 & 0 \\
2013 & 14 & $8.87 \times 107$ & $4.73 \times 107$ & 85.7 & 0 & 0 & 0
\end{tabular}

$N$ represents the number of colonies sampled for Nosema per year using qPCR analysis for species identification. Individual worker abdomens ( $n=10$ for each sample) were examined for DNA copy number for each Nosema spp. from each colony every year of sample collection. The mean DNA copy number was obtained for each worker group sampled 
N. apis (Bailey et al. 1983; Dainat et al. 2012; Antúnez et al. 2009), perhaps because some parasite variants may induce higher virulence in certain populations (Fries 2010, Higes et a. 2013, Roudel et al. 2013). This suggests that $N$. ceranae may be outcompeting $N$. apis in many regions where infection of both species has been analyzed using molecular techniques (Traver and Fell 2011a, b; Rangel et al. 2013).

Our current knowledge on the co-infection of honey bees by both species of Nosema is based on studies using only managed colonies kept in apiaries. Those that have looked at the levels of Nosema in feral honey bee populations have only reported data on $N$. apis infection. For example, Manning et al. (2007) looked at the levels of $N$. apis in feral colonies, settled swarms, and managed colonies in southwestern Australia in the early 2000s. They found that $77 \%$ of the feral colonies were infected with $N$. apis, with the infection ranging from 0 to 25 million spores/ bee. Interestingly, the severity of $N$. apis infection in feral colonies was significantly lower than in managed colonies, suggesting that feral colonies in that area of Australia have strains of $N$. apis that are less virulent, have better strategies for combating $N$. apis, or a combination of both.

In the USA, only two studies have explored infection of Nosema in unmanaged colonies, both reporting infection by $N$. apis alone. Similar to our findings, Gilliam and Taber (1991) reported very low $N$. apis spore counts in a feral honey bee population in Arizona, with only $42 \%$ of sampled colonies testing positive for $N$. apis spores. More recently, Szalanski (2014) explored the prevalence of $N$. apis in feral Africanized honey bees in five different states, including Texas. They found that less than $10 \%$ of the samples tested positive for $N$. apis, with infections being more common in Texas than in any other state. These results coincide with the first documented records of Nosema infections in feral honey bees by Bailey (1958, p. 93), who stated that "no firm general conclusion about disease in wild colonies can be drawn from the evidence given above, but its incidence usually seems to be low relative to that in beekeepers' colonies." Likewise, Ratnieks and Nowakowski (1989) reported no incidence of any disease in feral honey bee swarms.
Overall, pathogens and diseases affecting honey bees are primarily a problem of commercial beekeeping (Sherman et al. 1998). Beekeeping practices, like moving combs between colonies and apiaries, manipulating several apiaries with the same tools and equipment, or concentrating colonies into apiaries, among others, undoubtedly promote pathogen and parasite infectivity and transmission. However, this does not imply that unmanaged or feral honey bee colonies are not prone to diseases or that they do not serve as reservoirs for diseases. Under the right environmental conditions, the warm temperature inside a feral honey bee nest can drive parasitism and pathogen transmission. However, previous studies have suggested that feral colonies exhibit effective nest hygiene mechanisms that counteract these problems, including the secretion of antimicrobial and antifungal chemicals into honey, the use of tree resins (i.e., propolis) to coat crevices in the nest structure, defecation outside the nest, and the removal of dead and sick individuals (Visscher 1980; Seeley 1985; Drum and Rothenbuhler 1985). Given that the level of Nosema infections in feral honey bees appears to be low in all the studies conducted so far, it is likely that these bee populations are using effective mechanisms to control the levels of $N$. ceranae or $N$. apis in colonies. The use of propolis as an antimicrobial product used by honey bees to "self medicate" when confronted with certain infectious agents such as the fungal pathogen Ascophaera apis (Simone-Finstrom and Spivak 2012) could potentially be a well-suited strategy used by feral honey bees to combat Nosema infections. However, this remains to be investigated.

The overall low levels of Nosema infection in the WWR population of feral honey bees might in part be due to the time of year when samples were collected. In our study, Nosema levels were measured from samples collected in July, which is one of the hottest months of the year in Texas. Incidentally, this region of the USA suffered one of the most devastating droughts recorded in recent history in 2011 (Combs 2012), which likely influenced the colony-level dynamics of Nosema in feral honey bees at the WWR for our 2013 sampling period. More studies are needed to determine the seasonal changes in Nosema levels in this population during the entire year, particularly 
in the fall, and if the likelihood of Nosema infection is correlated with weather, as was found previously in other regions (Doull and Cellier 1961, Cantwell and Shimanuki 1970, Manning et al. 2007). Such studies have shown that Nosema levels are lowest during the summer months, while they go up in spring or autumn (Doull and Cellier 1961, Manning et al. 2007).

The endogenous life cycle of $N$. ceranae has been shown to be better adapted to withstand abrupt temperature changes, supporting the observed epidemiology of this microsporidian (MartínHernández et al. 2009). A recent study tested the survival capability of $N$. ceranae in different extreme temperature and desiccation settings (Fenoy et al. 2009). The authors found that compared to control spores that were kept at $4{ }^{\circ} \mathrm{C}$, about $90 \%$ of $N$.ceranae spores heated at $60{ }^{\circ} \mathrm{C}$ for $6 \mathrm{~h}$ remained viable. Furthermore, Cantwell and Shimanuki (1970) heated combs at $48.9^{\circ} \mathrm{C}$ for $24 \mathrm{~h}$ and noted a reduction in Nosema spore counts from 2.4 million spores/bee in unheated combs, to 1.2 million spores/bee in heated combs. Interestingly, heated combs subsequently exhibited an increase in honey production. Although not clearly stated in the methods, the authors most likely measured $N$. apis levels, as they do not mention the molecular tools needed to assess $N$. ceranae levels. Combined, results from both studies suggest that $N$. ceranae can tolerate the highest temperatures encountered in the summer at the WWR, which might be one of the reasons why it may have outcompeted $N$. apis in this system, especially when faced with increasing temperatures.

In conclusion, our study is the first to report the levels of both $N$. apis and $N$. ceranae in a feral honey bee population in the USA over a span of 20 years. We analyzed historical samples using qPCR, providing additional support for the potential for competitive displacement of $N$. apis by $N$. ceranae in a population of feral Africanized honey bees in south Texas that was co-infected with both Nosema species as far back as the early 1990s. More studies are needed looking at the seasonality of infection of both microsporidian species across time, and what mechanisms might be used by feral honey bee colonies to maintain relative low infection levels with Nosema spp. and, potentially, other pathogens.

\section{ACKNOWLEDGMENTS}

We thank Chris Garza, Kyle Harrison, Tuula Kantola, Rong Ma, Cassandra Sanabria, Elizabeth Walsh, and Michael Wong, for their help in locating and collecting honey bee samples from tree cavities at the WWR in 2013. We are also grateful to Dr. Maria Tchakerian and Tuula Kantola for their help in creating maps with GPS coordinates to locate tree cavities at the WWR. We thank WWR director Dr. Terry Blankenship and assistant director Dr. Selma Glasscock for their generosity in providing lodging and logistical support to our field team. We thank Grace Mulholland for her technical assistance during the molecular analysis of samples. This project was funded in part by a startup fund to J. Rangel by Texas AgriLife Research Hatch Project TEX09557, and by a National Science Foundation REU-EXITE grant to C. Sanabria, E. Walsh, and M. Wong (Grant no. 1062178). Funding for B. Traver was provided by the Agriculture and Food Research Initiative Competitive Grant no. 2010-67012-19924 from the US Department of Agriculture National Institute of Food and Agriculture.

Présence et niveau d 'infestation des espèces de Nosema dans une population d 'abeilles sauvages : une étude sur 20 ans

Apis mellifera / abeilles africanisées sauvages / Nosema apis / Nosema ceranae / PCR quantitative/ Texas

Prävalenz von Nosemaarten in einer wildlebenden Honigbienenpopulation: Eine 20 -jährige Langzeituntersuchung

Apis mellifera / Afrikanisierte Bienen / Nosema apis / Nosema ceranae / qPCR

\section{REFERENCES}

Alaux, C., Baldy, A., Brillard, J., Le Conte, Y., Belzunces, L.P., Cousin, M., Dussaubat, C., Brunet, J.-L., Tchamitchan, S., Mondet, F. (2010) Interactions between Nosema microspores and a neonicotinoid weaken honeybees (Apis mellifera). Environ. Microbiol. 12 (3), 774-782

Anderson, D.L., Giacon, H. (1992) Reduced pollen collection by honey bee (Hymenoptera, Apidae) colonies infected with Nosema apis and sacbrood virus. J. Econ. Entomol. 85(1), 47-51

Antúnez, K., Antúnez, R., Martín Hernández, L., Prieto, A., Meana, P., et al. (2009) Immune suppression in the 
honey bee (Apis mellifera) following infection by Nosema ceranae (Microsporidia). Environ. Microbiol. 11 (9), 2284-2290

Bailey, L. (1958) Wild honeybees and disease. Bee World 39, 92-95

Bailey, L. (1981) Honey Bee Pathology. Academic Press, London

Bailey, L., Ball, B.V. (1991) Honey bee Pathology, 2nd edn. Academic Press, London

Bailey, L., Bailey, B., Ball, J.N. (1983) Association of viruses with two protozoal pathogens of the honey bee. Ann. Appl. Biol. 103 (1), 13-20

Baum, K. (2003) Feral Africanized honey bee ecology in a coastal prairie landscape. Ph. D. Dissertation. Texas A\&M University, College Station, TX

Baum, K.A. (2005) Spatial and temporal distribution and nest site characteristics of feral honey bee (Hymenoptera: Apidae) colonies in a coastal prairie landscape. Environ. Entomol. 34 (3), 610-618

Blankenship, T. (2000) Ecological response of bobcats to fluctuating prey populations on the Welder Wildlife Foundation Refuge. Ph. D. Dissertation. Texas A\&M University, College Station, TX

Calderón, R.A. (2008) Presence of Nosema ceranae in Africanized honey bee colonies in Costa Rica. J. Apic. Res. 47 (4), 328-329

Cantwell, G.E. (1970) Standard methods for counting Nosema spores. Am. Bee J. 110, 222-223

Cantwell, G.E., Shimanuki, H. (1970) The use of heat to control Nosema and increase production for the commercial beekeeper. Am. Bee J. 110, 263

Chauzat, M.P. (2007) Presence of Nosema ceranae in French honey bee colonies. J. Apic. Res. 46(2), 127-128

Chen, Y., Chen, J., Evans, I.B., Smith, J. (2008) Nosema ceranae is a long-present and wide-spread microsporidian infection of the European honey bee (Apis mellifera) in the United States. J. Invertebr. Pathol. 97 (2), 186-188

Combs, S. (2012) The impact of the 2011 drought and beyond. Texas Comptroller of Public Account's office. Publication 96-1704, Printed online (February 2012)

Dainat, B., Dainat, J., Evans, Y., Chen, L., Gauthier, P., et al. (2012) Predictive markers of honey bee colony collapse. PLoS ONE 7 (2), e32151

Doull, K.M., Cellier, K.M. (1961) A survey of the incidence of Nosema disease (Nosema apis Zander) of the honey bee in south Australia. J. Insect Pathol. 3 (3): 280-288

Drawe D.L., A.D. Chamrad, T.W. Box. (1978) Plant communities of the Welder Wildlife Refuge. Rob and Bessie Welder Wildlife Foundation, Sinton, TX. [online]

Drum, N.H., Rothenbuhler, W.C. (1985) Differences in non-stinging aggressive responses of worker honeybees to diseased and healthy bees in May and July. J. Apic. Res. 24, 184-187
Fenoy, S., Rueda, C., Higes, M., Martín-Hernández, R., del Aguila, C. (2009) High-level resistance of Nosema ceranae, a parasite of the honeybee, to temperature and desiccation. Appl. Environ. Microbiol. 75, 68866889

Fries, I. (1993) Nosema Apis, a parasite in the honeybee colony. Bee World 74(1), 5-19

Fries, I. (1996) Nosema ceranae n. sp. (Microspora, Nosematidae), morphological and molecular characterization of a microsporidian parasite of the Asian honey bee Apis cerana (Hymenoptera, Apidae). Eur. J Protistol 32 (3), 356-365

Fries, I. (2003) African honey bees (Apis mellifera scutellata) and nosema (Nosema apis) infections. J. Apic. Res. 42 (1-2), 13-15

Fries, I. (2010) Nosema ceranae in European honey bees (Apis mellifera ). J. Invertebr. Pathol. 103, S73-S79

Fries, I., Ekbohm, G., Villumstad, E. (1984) Nosema apis, sampling techniques and honey yield. J. Apic. Res. 23 (2), 102-105

Giersch, T., Berg, F., Galea, M. (2009) Nosema ceranae infects honey bees (Apis mellifera) and contaminates honey in Australia. Apidologie 40 (2), 117-123

Gilliam, M., Taber, S.I. (1991) Diseases, pests, and normal microflora of honeybees, Apis mellifera, from feral colonies. J. Invertebr. Pathol. 58(2), 286-289

Hassanein, M.H. (1951) The influence of Nosema apis on the larval honeybee. Ann. App. Biol. 38(4), 844-846

Higes, M., Martin, R., Meana, A. (2006) Nosema ceranae, a new microsporidian parasite in honeybees in Europe. J. Invertebr. Pathol. 92 (2), 93-95

Higes, M., Higes, R., Martín Hernández, C., Botías, E., Bailón, A., et al. (2008) How natural infection by Nosema ceranae causes honeybee colony collapse. Environ. Microbiol. 10(10), 2659-2669

Higes, M., Higes, R., Martín Hernández, E., Garrido Bailón, C., Botías, A.N. (2009a) The presence of Nosema ceranae (Microsporidia) in North African honey bees (Apis mellifera intermissa). J. Apic. Res. 48(3), 217-219

Higes, M., Higes, R., Martín-Hernández, P., García-Palencia, P., Marín, A. (2009b) Horizontal transmission of Nosema ceranae (Microsporidia) from worker honeybees to queens (Apis mellifera). Environ. Microbiol. Rep. 1 (6), 495-498

Higes, M., Meana, A., Bartolomé, C., Botias, C., Martin-Hernandez, R. (2013) Nosema ceranae (Microsporidia), a controversial 21 st century honey bee pathogen. Environ. Microbiol. Rep. 5, $17-29$

Huang, W.-F., Huang, J.-H., Jiang, Y.-W., Chen, C.-H. (2007) A Nosema ceranae isolate from the honey bee Apis mellifera. Apidologie 38 (1), 30-37

Huang, W.-F., Huang, M., Bocquet, K.-C., Sung, J.-H., Jiang, Y.-W., et al. (2008) The comparison of rDNA spacer regions of Nosema ceranae isolates from different hosts and locations. J. Invertebr. Pathol. 97(1), 9-13 
Invernizzi, C., Abud, I., Tomasco, J., Harriet, G., Ramallo, J., et al. (2009) Presence of Nosema ceranae in honeybees (Apis mellifera) in Uruguay. J. Invertebr. Pathol. 101 (2), 150-153

Klee, J., Klee, A., Besana, E., Genersch, S., Gisder, A., et al. (2007) Widespread dispersal of the microsporidian Nosema ceranae, an emergent pathogen of the western honey bee, Apis mellifera. J. Invertebr. Pathol. 96(1), 1-10

Malone, L.A., Giacon, H.A., Newton, M.R. (1995) Comparison of the responses of some. New Zealand and Australian honey bees (Apis mellifera L) to Nosema apis Apidologie 26 (6), 495-502

Manning, R., Manning, K., Lancaster, A., Rutkay, L. (2007) Survey of feral honey bee (Apis mellifera) colonies for Nosema apis in Western Australia. Aust. J. Exp. Agric. 47 (7), 883-886

Martin-Hernandez, R., Meana, A., Prieto, L., Salvador, A.M., Garrido-Bailon, E., Higes, M. (2007) Outcome of colonization of Apis mellifera by Nosema ceranae. App. Environ. Microbiol. 73, 6331-6338

Martín-Hernández, R., Aránzazu, M., García-Palencia, P., Marín, P., Botías, C., Garrido-Bailón, E., Barrios, L., Higes, M. (2009) Effect of temperature on the biotic potential of honeybee microsporidia. App. Environ. Microbiol. 75, 2554-2557

Matheson, A. (1993) World Bee Health Report. Bee World 74 (4), 176

Matheson, A. (1996) World bee health update 1996. Bee World 77 (1), 45-51

Medici, S., Medici, E., Sarlo, M., Porrini, M., Braunstein, M. (2012) Genetic variation and widespread dispersal of Nosema ceranae in Apis mellifera apiaries from Argentina. Parasitol. Res. 110 (2), 859-864

Mendoza, Y., Antúnez, K., Branchiccela, B., Anido, M., Santos, E., et al. (2014) Nosema ceranae and RNA viruses in European and Africanized honeybee colonies (Apis mellifera) in Uruguay. Apidologie 45(2), 224-234

Moeller, F.E. (1956) The behaviour of nosema-infected bees affecting their position in the winter cluster. $\mathrm{J}$. Econ. Entomol. 49 (6), 743-745

Mulholland, G.E., Traver, B.E., Johnson, N.G., Fell, R.D. (2012) Individual variability of Nosema ceranae infections in Apis mellifera colonies. Insects 3 (4), 11431155

Natsopoulou, M.E., McMahon, D.P., Doublet, V., Bryden, J., Paxton, R.J. (2014) Interspecific competition in honeybee intracellular gut parasites is asymmetric and favours the spread of an emerging infectious disease. Proc. R. Soc. B. 282, 20141896

Paxton, R., Paxton, J., Klee, S., Korpela, I. (2007) Nosema ceranae has infected Apis mellifera in Europe since at least 1998 and may be more virulent than Nosema apis . Apidologie 38(6), 558-565

Pinto, M.A. (2004) Temporal pattern of Africanization in a feral honeybee population from Texas inferred from mitochondrial DNA. Evolution 58(5), 1047-1055
Pinto, M.A. (2005) Africanization in the United States: Replacement of feral European honeybees (Apis mellifera L.) by an African hybrid swarm. Genetics 170 (4), 1653-1665

Rangel, J., Traver, B., Stevens, G., Howe, M., Fell, R.L. (2013) Survey for Nosema spp. in Belize apiaries. J. Apic. Res 52 (2), 62-66

Ratnieks, F.L.W., Nowakowski, J. (1989) Honeybee swarms accept bait hives contaminated with American foulbrood disease. Ecol. Entomol. 14, 475-478

Rinderer, T., Sylvester, H.A. (1978) Variation in response to Nosema apis, longevity, and hoarding behavior in a free-mating population of the honey bee. Ann. Entomol. Soc. Am. 71 (3), 372-374

Roudel, M., Aufauvre, J., Corbara, B., Delbac, F., Blot, N. (2013) New insights on the genetic diversity of the honeybee parasite Nosema ceranae based on multilocus sequence analysis. Parasitology 140 , 1346-1356

Rubink, W.L., Luévano-Martinez, P., Sugden, E.A., Wilson, W.T., Collins, A.M. (1996) Subtropical Apis mellifera (Hymenoptera: Apidae) swarming dynamics and Africanization rates in northeastern Mexico and southern Texas. Ann. Entomol. Soc. Am. 89, 243-251

Seeley, T.D. (1985) Honeybee Ecology. Princeton University Press, Princeton, New Jersy

Sherman, P.W., Seeley, T.D., Reeve, H.K. (1998).Parasites, pathogens and polyandry in honey bees. Am. Nat. 151 (4), 392-396

Simone-Finstrom, M.D., Spivak, M. (2012) Increased resin collection after parasite challenge: a case of self-medication in honey bees? PLoS ONE 7 (3), e34601

Szalanski, A.L. (2014) Molecular detection of Nosema apis and $N$. ceranae from southwestern and South Central USA Feral Africanized and European honey bees, Apis mellifera (Hymenoptera: Apidae). Fla. Entomol 97 (2), 585-589

Taylor, O.R. (1988) Ecology and economic impact of African and Africanized honey bees. In: Bees, A.H., Mites, B. (eds.) G. R. Needham, R. E. Page, M. Delfinado-Baker and C. E. Bowman.), pp. 29-41. Ellis Horwood, Chichester, UK

Taylor Jr., O.R., Spivak, M. (1984) Climatic limits of tropical African honeybees in the Americas. Bee World 65, 38-47

Topolska G., S. Kasprzak. (2007) First cases of Nosema ceranae infection in bees in Poland. Med. Weter. 63(11(Suppl.)), 1504-1506.

Traver, B.E., Fell, R.D. (2011a) Prevalence and infection intensity of Nosema in honey bee (Apis mellifera L.) colonies in Virginia. J. Invertebr. Pathol 107 (1), 43-49

Traver, B.E., Fell, R.D. (2011b) Nosema ceranae in drone honey bees (Apis mellifera). J. Invertebr. Pathol. 107 (3), 234-236 
Traver, B.E., Anderson, Z.N., Anderson, Z.N. (2009) Homing endonucleases catalyze double-stranded DNA breaks and somatic transgene excision in Aedes aegypti. Insect Mol. Biol. 18(5), 623633

Vidau, C., Panek, J., Texier, C., Biron, D.G., Belzunces, L.P., Le Gall, M., Broussard, C., Delbac, F., El Alaoui, H. (2011) Differential proteomic analysis of midguts from Nosema ceranae -infected honeybees reveals manipulation of key host functions. J. Invertebr. Pathol. 121, 89-96

Visscher, P.K. (1980) Adaptations of honey bees (Apis mellifera) to problems of nest hygiene. Sociobiology 5, 249-260

Wang, D.I., Moeller, F.E. (1969) Histological comparisons of the development of hypopharyngeal glands in healthy and nosema-infected worker honey bees. J. Invertebr. Pathol. 14, 135-142

Wang, D.I., Mofller, F.E. (1970) The division of labor and queen attendance behavior of Nosema -infected worker honey bees. J. Econ. Entomol. 63(5), 1540-1541

Williams, G., Shafer, R.E.L., Rogers, D., Shutler, D. (2008) First detection of Nosema ceranae, a microsporidian parasite of European honey bees (Apis mellifera), in Canada and central USA. J. Invertebr. Pathol. 97 (2), 189-192

Wu, J.Y., Smart, M.D., Anelli, C.M., Sheppard, W.S. (2012) Honey bees (Apis mellifera) reared in brood combs containing high levels of pesticide residues exhibit increased susceptibility to Nosema (Microsporidia) infection. J. Invertebr. Pathol. 109, 326-329 